\title{
Some reflections about an Alabaster stele from Mari (Syria) and its possible relations to the Western Mediterranean.
}

\section{Algunas reflexiones sobre una estela de alabastro procedente de Mari (Siria) y sus posibles relaciones con el Mediterráneo Occidental.}

\author{
Thomas X. Schuhmacher \\ Universidad Autónoma de Madrid \\ Dedicated to the memory of my teacher Prof. Manfred O. Korfmann ( + ), Tübingen
}

Recibido: 07-10-2013

Aceptado: 20-10-2013

\section{Resumen}

El presente artículo trata de una estela de alabastro con decoración antropomorfa descubierta en las excavaciones de (Syria). Ya que en el contexto del Bronce Antiguo del Próximo Oriente contamos con pocas piezas parecidas, subrayamos sus posibles paralelos en el Mediterráneo Occidental. Así encontramos en la Península Ibérica todos los elementos presentes en la estela de Mari. Entre los artefactos tratados destacamos en primer lugar las placas de pizarra y la cerámica simbólica con su simbología de ojos. Esto se engloba en la cuestión de las relaciones del Calcolítico de la Península Ibérica con Oriente.

Palabras clave: Estela de alabastro - Mari- simbología de ojos - placas de pizarra- Península lbérica - Contactos a través del Mediterráneo.

\section{Abstract}

The present articles treats an alabaster stele with anthropomorphic decoraction discovered in the excavations of Mari $(\text { Syria })^{1}$. As there are only a few comparable objects in its Near Eastern Early Bronze Age context, special attention is drawn to the possible parallels in the Western Mediterranean. In fact it is on the Iberian Peninsula were all elements and symbols united on the Mari stele occur. Among the artefact groups in question we mention especially the slate slab idols and the so called Symbolkeramik, all with oculus symbolism. This implies the question of the eastern relations of Iberian Chalcolithic during the third millennium.

Keywords: Alabaster stele- Mari- Oculus symbolism- Slate slab idols- Symbolkeramik- Iberian PeninsulaMediterranean connections

\section{THE ARTEFACT}

At Mari (Syria) a pit was discovered beneath an altar consecrated to the deity Ninhursanga (Ninhursag). It contained fifty objects ${ }^{2}$, including an alabaster stele $35.3 \mathrm{~cm}$ tall and $18.5 \mathrm{~cm}$ wide (fig. 1). On the front the stele bears incised deco-

1 This text was originally thought to be published in the year 2004 in the European Journal of Archaeology. After several years awaiting in a drawer, I decided to publish the manuscript now in an updated version. In the meantime J. Ll. Pascual (2009:108) also noticed the great similarity betweeen the stele from Mari and the slate slabs of the Iberian Peninsula. ration. The most noticeable feature is two eyes formed of concentric circles. Short lines radiate from the outer circle. The eyebrows are suggested by a fine line each meeting in the middle and continuing as a thin line in the vertical - presumably representing the nose. This last ends in a circle

2 Museum Deir-ez Zor Inv. 19088 (TH97.154). Fortin, 1999:fig. p. 234, Cat. no. 295; Aruz, 2003:163, Cat. no. 106. The excavations are directed since 1979 by J.-C. Margueron, Paris (see Margueron, 1983. 1992. 2004). 


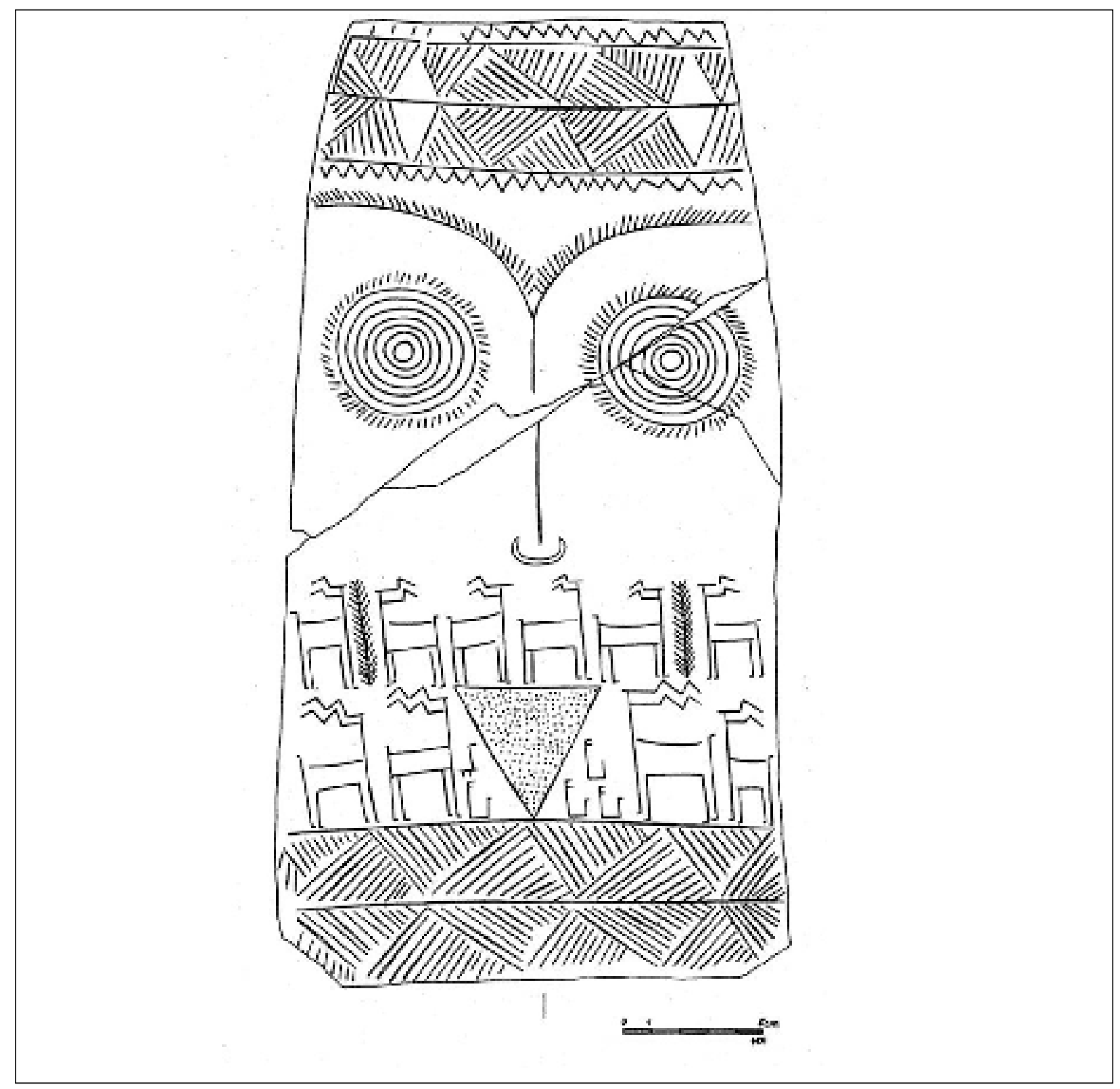

Figure 1. Mari. Alabaster stele. (drawing by M. Möck-Aksoy after Aruz, 2003:fig. 106).

which might represent the tip of the nose or the navel. Short fine lines also ascend from the eyebrow lines. The upper and lower ends of the stele are delimited by two horizontal bands containing alternating triangles. These in turn are filled in with parallel hatching. The double band on the upper end of the slab is also framed by an enclosing zigzag line. Just above the double band on the lower end of the stele and precisely centred there is a triangle standing on one of its points, filled with stippling. To judge from the overall composition - as well as with reference to contemporaneous idols from south-western Asia this represents the pubic area. Above this triangle there is a row of six stylised stags replete with antlers. The two at the ends are antithetically ordered. Between them there is in any case an ear of grain or tree motif. By contrast the two stags in the middle uniformly face to the right. Just to the left and right of the centred triangle two identically configured stags are arranged so that they look towards the middle of the stele. The two lower spandrels between those stags and the pubic area are filled with highly stylised birds.

The object in question was found in one of two foundational pits of a temple from the second city of Mari, belonging to Early Dynastic III (Margueron, 2004:111-114). The other pit contained some sixty stone vases and several sea shells of different species. Although these objects seem to have been deposited in the pits when founding the temple of Mari II, the parallels of 
most of the stone vessels and also of the stele directs us to earlier times. So most of the vessels seem to date to the beginning of the third millennium, that is the first city of Mari or Early Dynastic I and II. Most of the stone vessels show damages on their lips and the stele was broken in three fragments, but already repaired in antiquity with bitumen.

According to the radiocarbon and TL- dates available, Mari I was abandoned about $2700 \mathrm{BC}$. But it was not until 2550/ $2500 \mathrm{BC}$ that a completely new city was built. So there are arguments supporting the idea of the excavators, that the stele was uncovered when the second city was built and its ritual character was recognised or it received a special meaning because of its hazardous discovery. Therefore the stele was deposited in the pit under the temple of Mari II. In consequence we date the stele -in accordance with the excavators- to the beginning of the third millennium BC.

\section{Eastern Parallels}

\section{Slate slabs in the East}

The only apt parallels for our stele in the Near East come from Assur (Andrae, 1938:69-70 figs. 31a-d; Margueron, 2004:113). Four fragments of stone slabs show eyes formed of concentric rings. Short lines radiate from the outer circle. Eyebrows are marked by a fine line each, meeting in the middle, continuing in a vertical line and ending in a little circle. There are also stylised animals with antlers. In one case the upper end of the slab is delimited by a horizontal band containing alternating triangles. The only difference is the size, so the slabs of Assur are not longer than $5 \mathrm{cms}$. Furthermore the decoration is less carefully executed. The fragments are from contexts without a clear stratification, but it seems that they belong to the earliest moments of Assur.

\section{Oculus symbolism}

Although there are only few good parallels for the stele of Mari, its striking eyes are among the familiar elements. M. Korfmann (1999) has

3 In Tell Djudaydah however we recognise faces on ceramics reduced on eyes, nose and mouth (Amuq phase G) (Braidwood, 1960:fig. 290).

4 For the dating of Thermi see Yakar, 1985:107. drawn again attention to such oculus symbolism, basing himself in works by $\mathrm{M}$. Riemschneider (1953) and O.G.S. Crawford (1957). As he was able to establish, this noticeable emphasis on the eyes probably originated in northern Syria, central northern and western Turkey as well as the Cyclades at the close of the fourth millennium BC. From there it is supposed to have found its way west. The diagnostic finds came from Tell Brak, Troia I, Demircihüyük, Hassek Höyük (Behm-Blancke, 1981:20, 29 pl. 12,5.) and - earlier in date - Tulaylat Ghassul (Palestine) (Mallon, 1934:129ff frontispiece and pl. 67-70; North, 1961:frontispiece and pl. 2,V) .

In Tell Brak thousands of idols with these striking eyes have been found -especially in the grey stratum- under the so called eye-temple (Mallowan, 1947:32-39 figs. 1-5, pls. 25,1-9; 26,1-13). But here we treat with slab idols with trapezoidal body and differentiated head. The face is reduced on the striking eyes. One example shows like in Mari an animal with antlers and a bird. Mallowan dates the grey stratum as well as the eye-temple in the Janda - Nasi- period.

In Troia I and Thermi III (Lesbos) we find the representation of eyes on ceramic, dated in the early third millennium BC (Blegen et al., 1950:figs. 216,37-374; 238; 257; Lamb, 1936:pl. $17,368 \mathrm{e} ; 32,3 \mathrm{~b} .4)^{4}$.

\section{Pubic Triangle}

In Demircihüyük the oculus symbolism, as is the case with the piece from Mari, is linked inter alia with representations of the female genitals. Such eye representations are usually viewed as symbolising a 'mother goddess'. The figurines from Demircihüyük belong to the EBA 1 and 2, that is the beginning of the third millennium BC (Korfmann, 1999:fig. 2,10; Baykal-Seeher Obladen-Kauder, 1996:257-279, fig. 192, pl. 114-119).

We know other examples for the public triangle filled with stippling from tomb 107 in Demircihüyük-Sariket (Seeher, 2000:64-65, fig. 24,G.107c ), as well as Troia II (Schmidt, 1902:No. 7628; Baykal-Seeher - Obladen-
5 For the discussion and relevant publications see Korfmann, 1999:382-386. Against this interpretation Fleming, 1969. 
Kauder, 1996:275), IILsi:roğları (Renfrew, 1969:31, pl. 3c; Korfmann, 1999:391, fig. 4,24. For the dating of EBA 2 see Maran, 1998:424426, pl. 83), the region of Akhisar (Manisa) (Korfmann, 1979:197, pl. 29), Alisar Hüyük I, Г.tiyokuşu (Kansu, 1940:90-91, fig. 81, Ey.382; Ey.7), as well as Kusura B (Lamb, 1936b, 28, fig. 11,2; Lamb, 1937:251, fig. 17,7, pl. 84,8). All these examples date in the third millennium, more exactly in the EBA 2-3a, that is from 2700Bc to 2200 BC (Yakar, 1985:107,119, 137, 164, 175, 178, 197-199; Efe, 1988:fig. 98; Maran, 1998:pl. 83. For the dating of Troia II see also Korfmann Kromer, 1993:165; Easton, 2000:248-249).

More pieces of this representation come from Palestine, in Safadi (Beersheba) (Mellink- Filip, 1974:197, pl. XXII ). These pieces are a little older, dating to the fourth millennium BC. But also in the Ista:-Lemple of Mari figurines with this peculiar detail are dated to Early Dynastic I (Parrot, 1956:200-202, pl. 68,50.372.433).

\section{Animals with antlers}

As refers to the representation of animals we can also cite the pottery of Ninive V (Gut, 1995:108, No. 1118, 1135, 1136, 1156, 1161$1163,1167,1171-1173,1189,1203,1194$; Margueron, 2004:113). In fact painted animals with antlers, birds, fishes and vegetational motivs are Leitmotiv of this pottery from the end of the fourth millennium BC.

Although in consequence, the combination of oculus symbolism and triangular pubic area does not seem at all foreign to the Near East, the same does not hold for the overall composition and the simple form of a trapezium-shaped alabaster slab. We should look elsewhere for apt comparisons. As there are no such parallels -contemporaneaous in time- in the Eastern and Central Mediterranean- we indeed have to turn our steps to the Iberian peninsula.

6 Although I am conscient about the problematics of denominating these objects "idols", this is the term normally used in the bibliography, but of course we will have to question and talk about their use and meaning (Compare Hurtado, 2009: 139f).

7 For the history of research on and interpretation of the slate slabs see Gut, 1990:7-12. 18-24; Bueno Ramírez, 1992; Gonçalves, 1999:114-117 with references; Lillios, 2002; Gonçalves, 2004a. 2004b; Hurtado, 2008. 2009. Gut (1990:28) was able to cover 1898 genuine slate slabs and

\section{Western Parallels}

\section{Slate slab idols ${ }^{6}$ in the Iberian Peninsula}

A salient element of the Portuguese and Spanish Chalcolithic is what are called slate slabs $^{7}$. Even when most of these slabs are only decorated with geometric motifs, some do reveal the striking oculus representation ${ }^{8}$. Here the most noteworthy examples are the pieces from Huelva grave 40 (Santa Bárbara de Casa, Huelva), Pessilgais 2 (Alter do Chão, Portalegre, Alentejo), Cavaleiros 1 (Ponte de Sôr, Portalegre, Alentejo), Mertola (Beja, Alentejo), Farisoa 1 (fig. 2,1-5), Anta Grande do Zambujeiro, Comenda (all Reguengos de Monsaraz, Évora, Alentejo), Cueva de la Mora (Jabugo, Huelva), El Pozuelo 4 (Zalamea la Real, Huelva) and La Pijotilla (Badajoz) (Leisner, 1959:pl. 39,2; 48,4; 53,7.6; Almagro Gorbea, 1973:figs. 49,148; 49, 151. 154; Gonçalves, 2004a:fig. 7; Hurtado, 2009:pl. 13). Many of these pieces share with the stele from Mari the composition of the eyes formed of concentric circles, with in many cases rays radiating from them. In addition, eyebrows and/or noses are emphasized. Equally, triangles filled with hatching as we know it from the Mari stele are a common motif on slate slabs.

The pubic triangle, on the other hand, is identifiable on only a few objects, most notably a piece from Vega del Guadancil 1 (Garrovilas de Alconetar, Cáceres) (fig. 2,6) . In the case of this idol, however, all elements - eyes, eyebrows, nose, pubic triangle and, additionally, the arms have been picked out in relief.

The relative chronology of the slate slabs from the Iberian peninsula cannot yet be regarded as clarified. They occur most frequently in megalithic tombs, passage graves with corbelled vaults and rock-cut chamber tombs but are also encountered in settlements (Gut, 1990:35-37; Kunst, 2001:89). V. Gonçalves worked out the few find contexts which provided ${ }^{14} \mathrm{C}$ data (Gonçalves, 1999:114-

149 related objects. He estimates the total as 2000- 2500 exemplars.

8 Lillios, 2002:136. 141 was only able to identify 43 of the 680 slate slabs she included as having oculus representations.

9 This piece is actually made of sandstone rather than slate (Gut, 1990:30). Gut (1990:60, pl. 12, map 6) lists altogether three pieces with representations of the pubic triangle. Compare Gonçalves, 2004a:170f, 173f. 


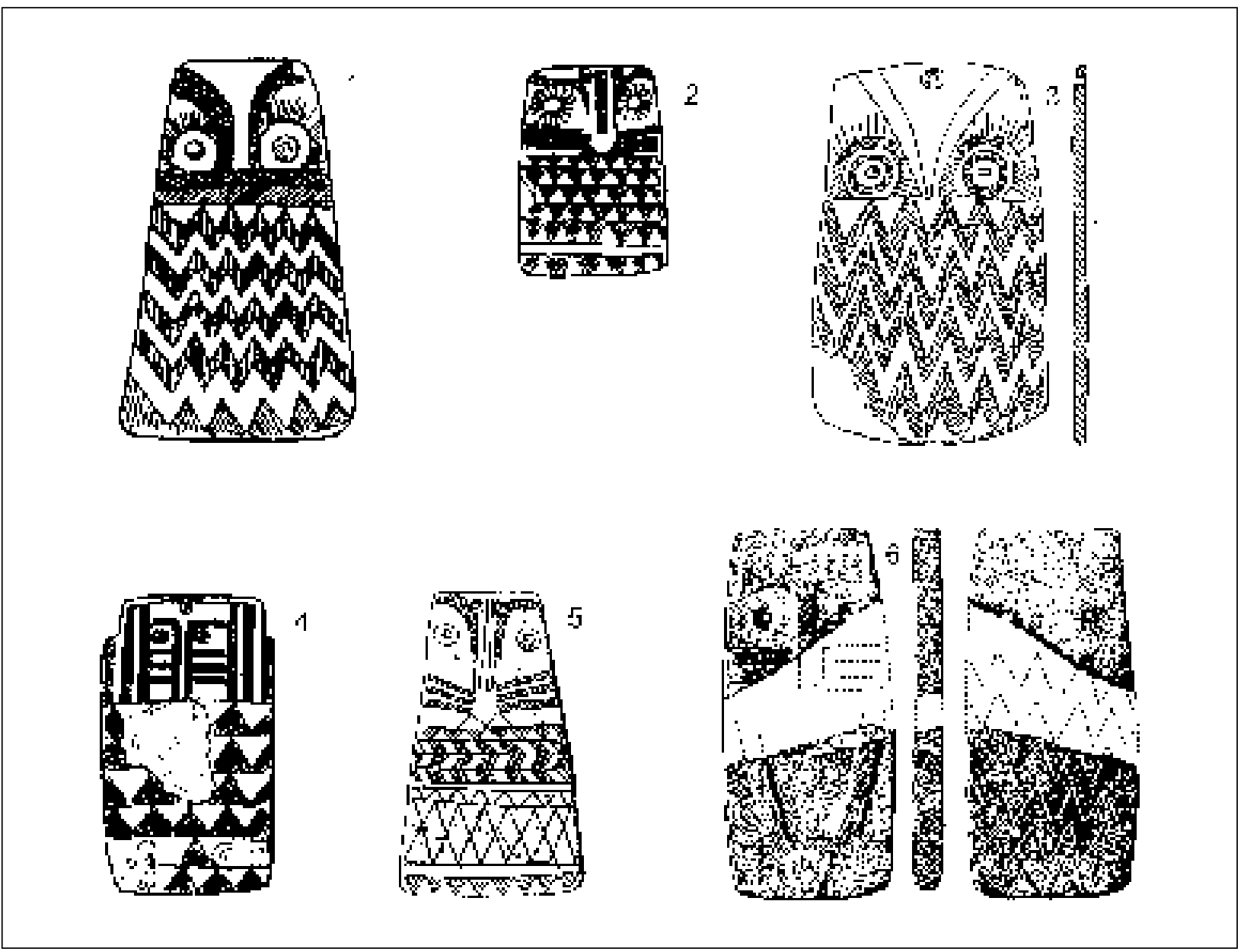

Figures 2. Iberian peninsula. Slate slab with oculus symbolism. 1 Farisoa; 2 Huelva grave 40; 3 Pessilgais 2; 4 Cavaleiros 1; 5 Mertola; 6 Vega del Guadancil 1. Scale 3:10 (after Leisner, 1959:pls. 7,20; 16,18.9; 34,5.2; 39,3; 49,10; 55,1.1).

117. See also Rodrigues 1986:15-22; Gonçalves, 2004b:56). According to these studies, the slate slabs date between ICEN-240: $4420 \pm 45 \mathrm{BP}=$ 3263-2929 calBC (Lapa do Fumo, Sesimbra, Setúbal) and ICEN-448:4140 $\pm 110 \mathrm{BP}=2876-$ 2586 calBC (Sala no. 1, Vidigueira, Beja) ${ }^{10}$. In the grave monument of Praia das Maçãs (Sintra) decorated slate slabs were only found in the Western chamber but not in the tholos situated in front of it (Leisner et al., 1969; Kalb, 1981, 59f; Gonçalves, 1982/83; Cardoso - Soares, 1995). Here we can differentiate two burial areas, Western chamber and tholos, constructed at different moments and with chronologically differentiated offerings. Three ${ }^{14} \mathrm{C}$-dates situate the use of the Western Chamber between 33122701 calBC.
So it seems clear that they belong to the end of the fourth and the first half of the third millennium BC, probably representing an older phase of the Pre-Beaker Chalcolithic. M.J. Almagro Gorbea, however, has established various groups on the basis of decoration type (Almagro Gorbea, 1973:181-218). Nevertheless, it has not yet been possible to establish more precise dates. Consequently, the question remains of whether stelae with decoration picked out in relief like the one from Vega del Guadancil might represent a somewhat younger form.

\section{Phalanx and tibia idols}

The emphasis on the eyes, however, does occur in similar form in other groups of idols from the Iberian peninsula, notably on phalanx

\footnotetext{
${ }^{10}$ Calibrated with OxCal v.4.2.3 at a range of 1 sigma (Bronk Ramsey, 2009).
} 
and tibia idols (Almagro Gorbea, 1973:153-180, figs. 26-28). Some phalanx idols are richly decorated (fig. 3). Here both the oculus representation and maybe also the pubic triangle occur. This richly decorated variant is found mainly in the Atlantic region of central and southern Portugal. Only a few exemplars, on the other hand, are known from south-eastern Spain (Almagro Gorbea, 1973:154 map 9).

As for tibia idols, few have been found ${ }^{11}$ and those few finds are mainly limited to the southeast and south of the Iberian peninsula (Almagro Gorbea, 1973:169, map 10; Molina-Burguera Pedraz, 2000:10-13, fig. 5; Soler, 2002:42-44, pls. $121 ; 124 ; 164 ; 171-173$; Pascual, 2009). Here the eyes, painted in red or ochre, are invariably emphasised. Sometimes the motif is doubled. Again the eyes are represented by concentric circles with rays radiating from them. They are also underscored by several concentric arcs above and below them. Triangles with filling are also a frequently encountered element of decoration. The pubic triangle seems to be represented in at least seven examples, so some from Cova de la Pastora (Almagro Gorbea, 1973:figs. 31. 32; Pascual, 2009:96).

One of the few dates available for a chronology is provided by finds from Ereta del Pedregal (Navarrés, Valencia) (Fletcher, 1961:12-13, pl. 4; Fletcher et al., 1964:8-10, fig. 4; Juan-Cabanilles, 1994; Castro et al., 1996:no. 964). Here richly decorated tibia idols occur from Level III down to the transition from Level IV to V of the excavation seasons prior to 1963 . It is, however, very difficult to link these levels from the excavation carried out prior to 1963 with later excavations. Nevertheless, we should be confronted with these tibia idol finds within Ereta del Pedregal Phase II,
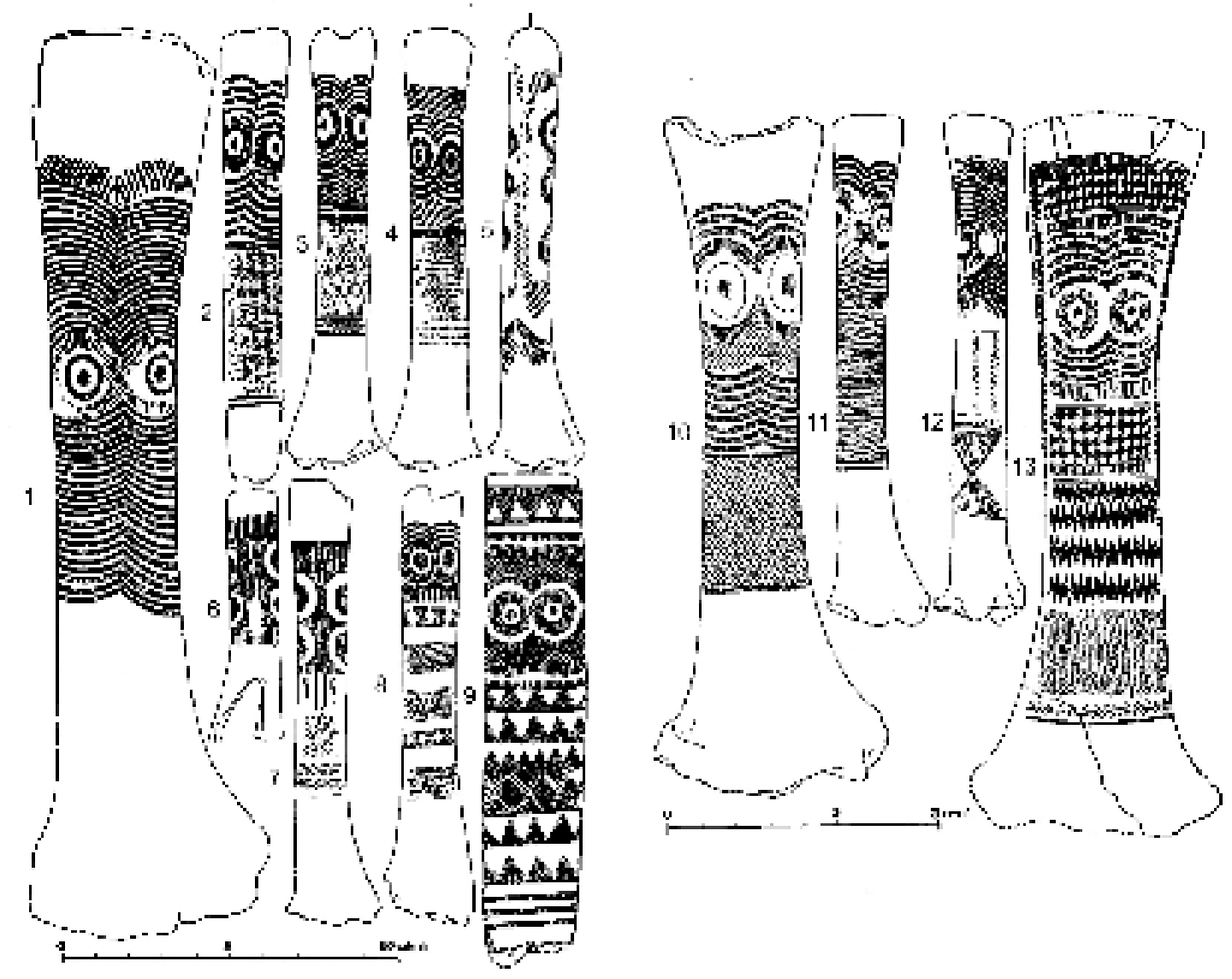

Figures 3. Almizaraque. Tibia idols. (after Leisner, 1943:pl. 92).

\footnotetext{
${ }^{11}$ J.Ll. Pascual (2009:87) could register 72 pieces for the País Valenciano.
} 
ie, from the pre-Bell Beaker Chalcolithic, that is from the beginning until the middle of the third millennium BC (Pla Ballester et al., 1983; Pla Ballester et al., 1983b; Pascual, 2009:82f).

Two such idols were found in Level II of Sector A in the settlement at Niuet (L'Alqueria d'Asnar, Alicante) (Bernabeu et al., 1994:25, 5962, fig. 5.4,1-3; Pascual, 2009: 86). For this level we have the following ${ }^{14} \mathrm{C}$ date from Beta$75222: 4490 \pm 80 \mathrm{BP}=3347-3091 \mathrm{calBC}$.

Another of these idols from Phase III at Terrera Ventura (Tabernas, Almería) should also be mentioned in this connection (Gusi - Olaria, 1991:234, fig. $178,4 .{ }^{14} \mathrm{C}$ dates Castro et al., 1996:Apéndice VI). The corresponding phase can be dated according to ten available ${ }^{14} \mathrm{C}$ dates between I-7417:4265 $\pm 95 \mathrm{BP}=3020-2680$ calBC and $\mathrm{I}-7422: 4010 \pm 95 \mathrm{BP}=2839-2349$ calBC.

This should make it clear that these idols belong to the pre-Bell Beaker Chalcolithic, with an absolute date in the 1 st half of the third millennium BC (Soler, 2002:42-44).

\section{"Oculados"}

M.J. Almagro Gorbea described a type of idol named cylindrical (Almagro Gorbea, 1973:103144). She has already distinguished different variants. They are usually undecorated or boast merely double or several zigzag lines alone or below and flanking the oculi (variants A and B). In addition, small numbers of richly decorated idols occur. Ultimately the term "oculados" is preferred for the ones decorated with eyes, as not all of them are cylindrical, but there is also a rectangular and flat variant (Hurtado, 2008. 2009). The eyes are their salient feature, too. Often the oculus zone is the only element represented (Leisner, 1943:pl. 92; Almagro Gorbea, 1973:figs. 22, 23, 24). Here too, representation of eyebrows is usual. In some instances, the arrangement of the hair is also indicated. Usually there are two or more zigzag lines below and flanking the eyes. Oculus motives are also seen on a few fragments of gold sheets, maybe coatings of plaques (Hurtado, 2009:pl. 16).

In the settlement of La Orden- Seminario de Huelva several of such idols appeared deposited in a pit probably as part of a ritual (González et al., 2008; Hurtado, 2009:168-170). This indicates that, although most of the "idolos oculados" are found in settlements, the contexts, where we find them might not be normal domestic but ritual ones.
Almagro Gorbea views variants $\mathrm{A}$ and $\mathrm{B}$ as the earlier, with the more richly decorated variants $\mathrm{C}$ and $\mathrm{D}$ belonging to the transition from the Early Chalcolithic to the Bell Beaker period and the time shortly after it. Finally, Hurtado and Perdigones subdivide these idols into several regional variants without chronological differentiation (Hurtado - Perdigones, 1983:55-56; Hurtado, 2008:pl. 2; Hurtado, 2009:pl. 19), seeing them as markers of territorial identity.

\section{"Symbolkeramik"}

In the overarching context, the pottery known as Symbolkeramik should also be mentioned. On it, too, the oculus (and rayed sun) are the most frequently encountered representations. There are good examples of oculi from the following graves: Olival da Pega 1 (Reguengos de Monsaraz, Évora) (Leisner, 1959:pl. 41,14), Los Millares 5, 7, 9, 15, 21, 37 and 40 (Santa Fé de Mondújar, Almería), Hoya del Conquil 46 (Gorafe, Granada), Almizaraque (Cuevas de Almanzora, Almería) and Vélez Blanco (Almería) (Leisner, 1943:pls. 20,1.6; 20,2.7; 96) and from the settlement of La Pijotilla (Badajoz) (Hurtado, 2009:fig. 6). The eyes are again represented by concentric circles and rays. As in the piece from Mari, two arcs form eyebrows, with lines rising from them. In Los Millares 4 dot-filled triangles occur below the oculi yet here the triangles are standing on a narrow side instead of the point. (Leisner, 1943:pl. 96, 5). In same cases it seems like the circles with rays represent not eyes but suns, planets and stars (See Esacena 2011/12).

A very apt comparison with the Mari stele is furnished by the beaker from the Monte do Outeiro (Aljustrel, Beja, Alentejo) corbel-vaulted grave (Leisner, 1965:pl. 128,1) (fig. 4,1-2). In this instance, most of the elements found on the Mari stele are united on a single piece. Eyes, eyebrows, nose and pubic triangle are represented in a way very similar to the representation from Mari. An additional element is the familiar 'facial tatoo' but the stags are missing. Moreover, the face is bounded at top and bottom by a horizontal band filled with alternating hanging and standing dotfilled triangles.

The exemplars from Los Millares 7 and 15 are, however, the ones that unite the oculus symbolism with a further element found on the stele from Mari, that is, the stags (Leisner, 1943:pls. 

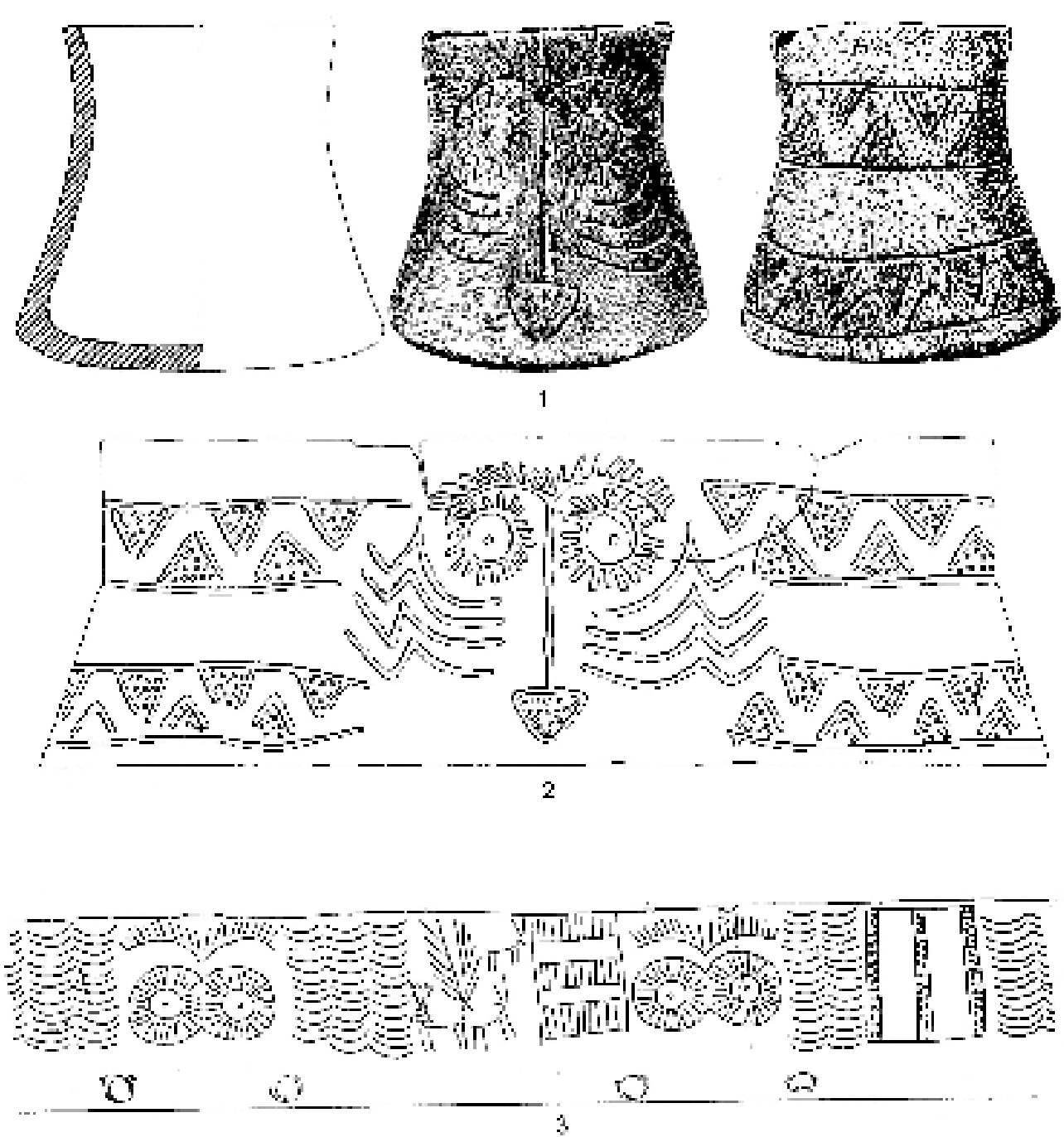

r o

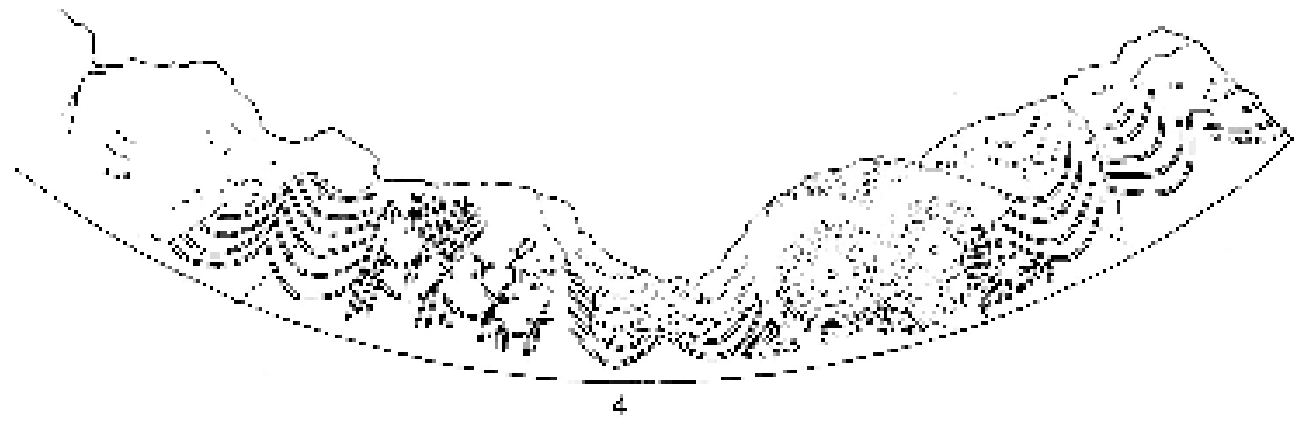

Figures 4. Iberian peninsula. Chalcolithic Symbolkeramik. 1-2 Monte do Outeiro; 3 Los Millares grave 15; 4 Los Millares grave 7. Scale 3:10 (1-2 after Leisner, 1965:pl. 128,1; 3-4 after Leisner, 1943:pl. 96, 1.6).

20,6) (fig. 4,3-4). In each case, a herd is probably indicated, with a stag sporting magnificent antlers and several does. Here to, as in Mari, they are indicated by a few lines. The bodies of the animals in Mari are formed of rectangles but of arcs in Los Millares.
As for the representations of stags, we should like to point out the Vila Nova de Sao Pedro I rectangular or square clay plaques (Almagro Gorbea, 1973 :fig. 54). Here stags also occur in addition to the frequently encountered 'sun symbol'. In this case the stags' bodies are actually indicated by rectangles. 
Garrido Pena and Muñoz López-Astilleros have also pointed out again in this connection stylised representations of stags, eyes/ suns or both on Bell Beaker pottery from Palmela tomb 3 (Portugal), Portucheira (Portugal), Tituaria (Portugal), Brenes (Carmona, Sevilla), Córdoba, El Olivar del Pósito (Santaella, Córdoba), Cerro de la Virgen (Orce, Granada), Ciavieja (El Ejido, Almería), Las Carolinas (Madrid), El Ventorro (Madrid), Camino de Yeseras (Madrid), La Escarapela (Borox, Toledo), El Pico del Castro (Quintanilla de Arriba, Valladolid), Portimayor II (Las Bardenas Reales, Navarra) (Leisner 1961; Garrido Pena - Muñoz López-Astilleros, 2000:figs. 2-6; Martin Socas - Camalich, 1982:285-286; Liesau et al., 2008:fig. 17b).

Symbolkeramik was long regarded as diagnostic for Los Millares I and Vila Nova de Sao Pedro I (Early Chalcolithic) (Martin Socas Camalich, 1982:279-290). The find contexts in the graves, however, suggest that the Symbolkeramik belongs mainly to an advanced phase of the Early Chalcolithic and the subsequent Bell Beaker period.

On the other hand, Gavilán and Vera have presented several pottery sherds from cave sites in southern Spain with similar decoration motifs in the form of rayed suns and oculi (Gavilán - Vera 1993). In this case, the pottery differs in form from the Symbolkeramik since the upper part of troncoconic pots resembles a truncated pyramid, which suggests a Late or even Middle Neolithic date $^{12}$. The authors would, therefore, like to differentiate these fragments from the actual Symbolkeramik yet nonetheless recognize a genetic link. Rayed sun and oculus representations on pottery must, consequently, have been known on the southern Iberian peninsula from the late fourth millennium BC. This may be affirmed by the so-called Venus of Gavà, who should be dated to the late fourth or the first half of the third millennium BC (Bosch - Estrada, 1994:287-291; Bosch - Estrada, 1994b).

\section{Other elements}

A horizontal double band finishes off the stele from Mari at the top. This might be an indication of a hair arrangement, jewellery worn on the head or a head-dress. A comparison is suggested with the upper boundary of the baetyl from the Casainhos dolmen (Loures, Lisboa, Estremadura) (Leisner, 1965:pl. 23,78). It sports a total of nine narrow bands demarcated by horizontal lines. They are filled with zigzag lines or hatching. In this case, too, a human face is intended. Instead of the eyes, however, only the eyebrows and nose are represented.

\section{Conclusions}

As we have shown, in the Near East there are only few comparisons for the stele from Mari. It does, however, resemble other representations of the oculus symbolism frequently encountered in the Near East. As Korfmann has shown, this symbolism had already made its way westward by the close of the fourth millennium BC (Korfmann, 1999). Korfmann has in this connection provided important pointers concerning also the spread of the cross band and of bone symbolism.

But it is on the Iberian peninsula especially that all elements and symbols united on the Mari stele occur. In fact, the resemblance of the Mari slab with the flat stone slabs with oculus representations from the third millennium BC Iberian Peninsula is striking. Slate slabs occur frequently in central and southern Portugal as well as Extremadura and Andalusia in Spain (Gut, 1990; Lillios, 2002:136f, fig. 1; Gonçalves, 2004; Hurtado, 2008: 3f; Gonçalves, 2011: 29-32), being the Portuguese Alentejo and especially the district of Évora, the region which delivered the greatest amount of them. Even though none of the stone slabs hitherto found on the Iberian peninsula has the combination of elements found in Mari, a link cannot be dismissed out of hand. The slate slabs only reveal a limited repertoire of symbols but the overall composition is similar in each case yet these are invariably individual pieces (Gut, 1990:66; Lillios, 2002:136). No two are precisely identical.

There has been several intents of deciphering the function and meaning of these slate slabs. Some see the anthropomorphic plaques as depictions of deities, more concrete of a Mothergoddess (Almagro Gorbea, 1973; Rodrigues, 1986; Gonçalves, 1999). Bueno Ramírez (1992) saw the slabs as ethnic identifiers of contemporary groups and their distribution as evidence of

\footnotetext{
${ }^{12}$ The pieces are without a stratigraphic context.
} 
regional exchange systems. Lillios (2002) went back to an older affirmation of Lisboa (1985) and views the slate slabs as heraldic symbols instead of idols. Especially the fact that the slabs with anthropomorphic representations are very scarce is taken as an argument against their interpretation as deities.

Slate plaques are found almost exclusively in tombs and only a few fragments have been unearthed in settlements (Lillios, 2002; Gonçalves, 2003:137-140; Gonçalves, 2004b:61f), with the exception of Cabeço do Pé da Erra (Santarém), where a possible plaque production centre has been documented. In spite of the relatively great number of documented slate slabs, Gut calculated a total of 1898 documented pieces and a total number of 2000-2500, Gonçalves estimated it on 4000 , it is clear that they do not appear in every tomb and do not accompany all dead corpses. It is therefore clear that not everybody received a plaque. But there seems to be a certain concordance between slabs and dead corpses, so there is never more than one plaque per corpse. And we do have a few finds, where the exact findspot of the plaques in the burial was documented, this is the chest of the dead (Gonçalves, 2011:31f). The small proportion of anthropomorphic or zoomorphically decorated slate slabs in relation to a relatively large whole indicates that especially these pieces were something special and this finding would actually support the assumption that a 'religious or magic' function should be assigned to them ${ }^{13}$.

It seems clear that the slate slabs of the western Iberian Peninsula were no ordinary object, but restricted to a certain group of persons. And we are talking of objects closely related to funerary contexts. They show a reduced number of symbols, among them even more restricted are the striking eyes with the eyebrows, the nose and the pubic triangle. The stags, present on the slab of Mari, are missing on slate slabs, but occur together with the oculus symbol e.g. on the Symbolkeramik. We are therefore talking about symbolic or magic-religious objects transmitting

${ }^{13}$ One should bear in mind that Lillios (2002:141) speaks of 43 slabs with oculus representations from a total of 680 she has recorded. Only in nine cases were other parts of the body, such as arms or noses, represented in addition.

${ }^{14}$ See on this Chapman, 1990:30-34; Cordes et al.,1990; Blance, 1995; Korfmann, 1995; Korfmann, 1999:381- 397; Arteaga, 2001:165-171. a message. This message was of course understood in the production and main distribution centre of the slabs, but also beyond, as the slabs in occasions were exchanged (or their bearer moved?) beyond their main distribution centre in the Alentejo towards the peninsula of Lisbon and Setúbal, the Spanish Extremadura and Andalusia. In fact the different populations of the southern part of the Iberian Peninsula, although differing in their respective cultural expression but sharing some common traits, seem to share the same symbols but represented in different ways (Pascual 2009: 108-111). So whereas in the Alentejo we do find the slate slabs, in Extremadura and Western Andalusia the oculus symbol is present on different types of "oculados" (or cylindrical idols) and in the East decorates long bones.

The resemblance of the slate slabs of the Iberian Peninsula and the slab of Mari is indeed obvious, the same overall composition and the same symbols (except the stags and birds). Although the different symbols of the Mari slab are present in the Near East, this is not true for the overall composition and the combination of the whole of these symbols. That we can only find on the Iberian Peninsula, perfectly represented in the beaker from Monte do Outeiro which seems a compelling argument for a link.

One problem we have to deal with is, that we do not have any similar objects from the area between the eastern and the western Mediterranean, although it seems very likely that such long-distance contacts were made with the help of a series of short-distance "stepping stones". The only object we have to support this is a little slab with an owl-like face and a hole on the upper end from Bau 'Porcus (Oristano) in Sardinia (Atzeni, 1973/74:18-19, pl. 7,1; Höckmann, 1987:94, fig. 21a).

It is here not the place to come back to the old question of the Eastern connection of the Iberian chalcolithic $^{14}$, which has long been the subject of contention. But a project of investigation about ivory delivered new data on this behalf ${ }^{15}$. So we could show by scientific analysis that since the

${ }^{15}$ The investigation projects SCHU 1539/2 and SCHU 1539/3 were financed by the German Science Foundation (Deutsche Forschungsgemeinschaft, DFG, Bonn) and based in the German Archaeological Institute (DAI) of Madrid. 
beginning of the Chalcolithic (end of the $4^{\text {th }}$ and beginning of the $3^{\text {rd }}$ millennium $\mathrm{BC}$ ) and during the whole $3^{\text {rd }}$ millennium BC Asian ivory was in circulation in South-Eastern and South-Western Iberian Peninsula (Nocete et al., 2013; García Sanjuán et al., 2013). This ivory probably came from the so called Syrian Elephant, in fact an extinct variant of the modern Asian Elephant (Elephas maximus), who lived till the $7^{\text {th }}$ century $\mathrm{BC}$ in the whole region from Palestine, Syria to the Middle Euphrates (Pfälzner, 2013). From there raw material came to the Iberian Peninsula, especially to the big fortified or ditched settlements like Los Millares (Almeria) and Valencina de la Concepción (Seville). The find of an ivory workshop in Valencina de la Concepción shows the manufacture of ivory objects made of Asian ivory by the begnning of the $3^{\text {rd }}$ millennium BC. From there the objects were distributed further inland and consumed. In this context the sharing of common symbols or magic-religious objects or the movement of people does not seem to be so strange.

\section{ACKNOWLEGEMENTS}

I am indebted to my teacher, M. Korfmann ( $\dagger)$, Tübingen, the first to recognize the connection, for drawing my attention to the piece, for his advice and comments on the text. In the same way I would like to thank M. Bartelheim, Tübingen for his comments on the text and his advice. I would also like to thank M. Möck-Aksoy for the drawing of the stele and J. L. Clough-Laub (both Tübingen) for translating a first version of my original German text to English.

\section{BIBLIOGRAPHY}

ALMAGRO-GORBEA, M. (1973): Los ídolos del Bronce I hispano. Bibliotheca Praehistorica Hispana XII. Madrid.

ANDRAE, W. (1938): Das wiedererstandene Assur. J.C. Hinrichs Verlag. Leipzig.

ARTEAGA, O. (2001): Fuente Álamo im Territorium von El Argar. In: Schubart, H. - Pingel, V. Arteaga, O. eds., Fuente Álamo. Die Grabungen von 1977 bis 1991 in einer bronzezeitlichen Höhensiedlung Andalusiens, Madrider Beiträge 25, Verlag Philipp von Zabern, 161-203. Mainz.

ARUZ, J., ed., (2003): Art of The First Cities. The Third Millennium B.C. from the Mediterranean to the Indus, Metropolitan Museum of Art. New York.
ATZENI, E. (1973/74): Nuovi idoli della Sardegna Prenuragica. Studi Sardi 23-1, 3-51.

BAYKAL-SEEHER, A.; OBLADEN-KAUDER, J. (1996): Die Kleinfunde, Demircihüyük IV, Verlag Philipp von Zabern, Mainz.

BEHM-BLANCKE, M.R. (1981): Hassek Höyük. Vorläufiger Bericht über die Ausgrabungen der Jahre 1978-1980. Istanbuler Mitteilungen 31, 5-93.

BERNABEU AUBÁN, J., et al. (1994): Niuet (L'Alqueria d'Asnar) poblado del III milenio a.C. Recerques del Museu d'Alcoi 3, 9-74.

BLANCE, B.E (1995): Copper Age Colonies seen from the Eighties. In: Kunst, M.. ed. Origens, Estruturas e Relações das Culturas Calcolíticas da Península Ibérica, Actas das I Jornadas Arqueológicas de Torres Vedras 1987, Trabalhos de Arqueologia 7, 55-59. Lisboa.

BLEGEN, C.W. et al. (1950): Troy Vol. 1. The First and second settlements, Princeton University Press, New Jersey.

BOSCH, J.; ESTRADA, A. (1994): La Venus de Gavà. Rubricatum 0, 287-291.

BOSCH ARGILAGOS, J.; ESTRADA MARTÍN, A. (1994b): La Venus de Gavà (Barcelona). Una aportación fundamental para el estudio de la religión neolítica del suroeste europeo. Trabajos de Prehistoria 51-2, 149-158.

BRAIDWOOD, R.J.; BRAIDWOOD, L.S. (1960): Excavations in the Plain of Antioch I. The Earlier Assemblages A-J. The University of Chicago, Chicago.

BRONK RAMSEY, C. (2009): Bayesian analysis of radiocarbon dates. Radiocarbon 51,1, 337-360.

BUENO RAMÍREZ, P. (1992): Les plaques décorées alentéjanes: approche de leur étude et analyse. L'Anthropologie 96, 573-604.

CARDOSO, J.L.; MONGE SOARES, A.M. (1995): Sobre a cronologia absoluta das grutas artificais da Estremadura portuguesa. Al-madan, 4, 10-13.

CASTRO MARTÍNEZ, P.V. et al. (1996): Cronología de la Prehistoria Reciente de la Península Ibérica y Baleares (c.2800-900 calANE), BAR Int. Series 652, Tempus Reparatum, Oxford.

CHAPMAN, R. (1990): Emerging Complexity, Cambridge University Press, Cambridge.

CORDES, K.; GUT, A.; SCHUHMACHER, TH. (1990): Zur Frage der 'Schiess-Scharten' in Zambujal. Madrider Mitteilungen 31, 83-108. 
CRAWFORD, O.G.S. (1957): The Eye Goddess, Phoenix House, London.

EASTON, D.F. (2000): A pair of pendant earrings of Trojan type. Studia Troica 10, 239-250.

EFE, T. (1988): Die Keramik 2. C Die frühbronzezeitliche Keramik der jüngeren Phase, Demircihüyük III,2, Verlag Philipp von Zabern, Mainz.

ESCACENA CARRASCO, J.L. (2011/12): El firmamento en un cuenco de cerámica. Viaje a las ideas calcolíticas sobre la boveda celeste. Cuadernos de Prehistoria y Arqueología de la Universidad Autónoma de Madrid 37-38, 153-194.

FLEMING, A. (1969): The myth of the mother-goddess. World Archaeology 1, 247-261.

FLETCHER VALLS, D. (1961): La Ereta del Pedregal (Navarrés, Valencia). Archivo de Prehistoria Levantina 9, 79-96.

FLETCHER VALLS, D.; PLA BALLESTER, E.; LLOBREGAT CONESA, E. (1964): La Ereta del Pedregal (Navarrés, Valencia), Excavaciones Arqueológicas en España 42, Madrid.

FORTIN, M. (1999): Syrien, Wiege der Kultur, Exposition Basel, Verlag Philipp von Zabern, Mainz.

GARCÍA SANJUÁN, L.; LUCIÁÑEZ TRIVIÑO, M.; SCHUHMACHER, TH. X.; WHEATLEY, D.; BANERJEE, A. (2013): Ivory craftsmanship, trade and social significance in the southern Iberian Copper Age: the evidence from the PP4Montelirio sector of Valencina de la Concepción (Seville, Spain). European Journal of Archaeology (Online-Version: DOI: 10.1179/1461957113Y.0000000037).

GARRIDO PENA, R.; MUÑOZ LÓPEZASTILLEROS, K. (2000): Visiones sagradas para los líderes. Cerámicas campaniformes con decoración simbólica en la Península Ibérica. Complutum 11, 285-300.

GAVILÁN CEBALLOS, B.; VERA RODRÍGUEZ, J.C. (1993): Cerámicas con decoración simbólica y cordón interior perforado procedentes de varias cuevas situadas en la Subbética cordobesa. SPAL 2, 81-108.

GONÇALVES， J. L. MARQUES (1982/83): Monumento pré-histórico da Praia das Maçãs (Sintra). Notícia preliminar. Sintria 1/2, 29-58.

GONÇALVES, V.S. (1999): Reguengos de Monsaraz, territórios megalíticos. Lisboa.
GONÇALVES, V.S. (2003): Manifestações do sagrado na Pré-História do Occidente peninular: 4. A "síndrome das placas loucas". Revista Portuguesa de Arqueologia 6,1, 131-157.

GONÇALVES, V.S. (2004a): Manifestações do sagrado na Pré-História do Occidente peninsular. 5. O explícito e o implícito. Breve dissertação, invovcando os limites fluidos do figurativo, a propósito do significado das placas de xisto gravadas do terceiro milénio a.n.e.. Revista Portuguesa de Arqueologia 7,1, 165-183.

GONÇALVES, V.S. (2004b): As deusas da noite: o projecto <Placa Nostra> e as placas de xisto gravadas da região de Évora, Revista Portuguesa de Arqueologia 7,2, 49-72.

GONÇALVES, V.S. (2011): As placas de xisto gravadas (e os báculos) do sítio do Monte da Barca (Coruche), Cadernos de Uniarq 7, Lisboa.

GONZÁLEZ GONZÁLEZ, B. et al. (2008): Depotfund zylinderförmiger Idole des 3. Jts. v. Chr. aus La Orden- Seminario (Huelva). Madrider Mitteilungen 49, 1-28.

GUSI I JENER, F.; OLARIA I PUYOLES, C. (1991): El poblado neo-eneolítico de Terrera-Ventura (Tabernas, Almería), Excavaciones Arqueológicas en España 160, Madrid.

GUT, A., (1990): Die Schieferplattenidole Portugals anhand des Nachlasses von Vera Leisner. Tübingen University: unpublished Master of Arts dissertation.

GUT, R. V.,, (1995): Das prähistorische Ninive. Zur relativen Chronologie der frühen Perioden Mesopotamiens. Baghdader Forschungen 19, Verlag Philipp von Zabern, Mainz.

HÖCKMANN, O. (1987): Frühbronzezeitliche Kulturbeziehungen im Mittelmeergebiet unter besonderer Berücksichtigung der Kykladen. In: Buchholz, H.-G. ed., Ägäische Bronzezeit, Wissenschaftliche Buchgesellschaft, 53-120. Darmstadt.

HURTADO, V. (2008): Ídolos, estilos y territorios de los primeros campesinos en el sur peninsular". In Cacho Quesada, C.; Maicas Ramos, R.; Martos, J.A., Martínez, Ma .I. eds., Acercándonos al pasado. Prehistoria en 4 actos. Ministerio de Cultura. Museos Estatales. Museo Arqueológico Nacional y CSIC. Edición en CD y web del MAN. Madrid. (Edicción digital:

http://man.mcu.es/museo/JornadasSeminarios/acercandonos al pasado.html) 
HURTADO, V. (2009): Representaciones simbólicassitios, contextos e identidadesterritoriales en el Suroeste peninsular. In: Cacho, C.; Maicas, R.; Galán, E.; Martos, J.A. eds., Ojos que nunca se cierran, Museo Arqueológico Nacional. Madrid. (Edicción digital: http://man.mcu.es/publicaciones/OJOS/OJOS0902.html)

HURTADO, V.; PERDIGONES, L. (1983): Ídolos inéditos del calcolítico en el Sudoeste. Madrider Mitteilungen 24, 46-58.

JUAN-CABANILLES, J. (1994): Estructuras de habitación en la Ereta del Pedregal (Navarrés, Valencia). Resultados de las campañas de 19801982 y 1990. Saguntum 27, 67-97.

KALB, P. (1981): Zur relativen Chronologie portugiesischer Megalithgräber. Madrider Mitteilungen 22, 55-77.

KANSU, S.A. (1940): Les fouilles o" 6yjorizun (1937) entreprises par la societé d'histoire turque. Ankara.

KORFMANN, M. (1979): Eine weibliche Gottheit in der Frühbronzezeit Anatoliens. Prähistorische Zeitschrift 54, 187-200.

KORFMANN, M. (1995): Cerâmica com decoração brunida da região de Tróia e a sua cronologia, assim como factores inovadores em relação a alguns outros fenómenos que provêm provavelmente das regiões a Leste do Mar Mediterráneo. In: Kunst, M. ed., Origens, Estruturas e Relações das Culturas Calcolíticas da Península Ibérica, Actas das I Jornadas Arqueológicas de Torres Vedras 1987, Trabalhos de Arqueologia 7, 345354. Lisboa.

KORFMANN, M. (1999): Ost-West-Beziehungen im Mittelmeerraum am Beispiel einer Idolgruppe. In: Festschrift für Günter Smolla, Materialien zur Vor- und Frühgeschichte von Hessen 8, Selbstverlag des Landesamtes für Denkmalpflege Hessen, 381-397. Wiesbaden.

KORFMANN, M.; KROMER, B. (1993): Demircihÿük, Beflik-Tepe, Troia- Eine Zwischenbilanz zur Chronologie dreier Orte in Westanatolien, Studia Troica 3,135-171.

KUNST, M. (2001): Kupferzeit der Iberischen Halbinsel. In: Blech, M.; Koch, M.; Kunst, M. eds., Hispania Antiqua. Denkmäler der Frühzeit, Verlag Philipp von Zabern, 67-99. Mainz.

LAMB, W. (1936): Excavations at Thermi in Lesbos, Cambridge University Press, Cambridge.
LAMB, W. (1936b): Excavations at Kusura near Afyon Karahisar, Archaeologia 86, 1-64.

LAMB, W. (1937): Excavations at Kusura near Afyon Karahisar: II, Archaeologia 87, 217-273.

LEISNER, G. and V. (1943): Die Megalithgräber der Iberischen Halbinsel. Der Süden. RömischGermanische Forschungen 17, Walter de Gruyter, Berlin.

LEISNER, G. and V. (1959): Megalithgräber der Iberischen Halbinsel. Der Westen. 2. Lieferung. Madrider Forschungen I 2, Walter de Gruyter, Berlin.

LEISNER, V. (1961): Innenverzierte Schalen der Kupferzeit auf der Iberischen Halbinsel. Madrider Mitteilungen 2, 11-34.

LEISNER, V. (1965): Die Megalithgräber der Iberischen Halbinsel. Der Westen. 3. Lieferung, Madrider Forschungen I 3, Walter de Gruyter, Berlin.

LEISNER, V.; Zbyszewski, G.; da Veiga Ferreira, O. (1969): Les monuments préhistoriques de Praia das Maçãs et de Casainhos, Lisboa.

LIESAU, C. et al. (2008): Un espacio compartido por vivos y muertos: El poblado calcolítico de fosos de Camino de (San Fernando de Henares, Madrid). Complutum 19, 97-120.

LILLIOS, K. (2002): Some new views of the engraved slate plaques of southwest Iberia. Revista Portuguesa de Arqueologia 5,2: 135-151.

LISBOA, I.M.G. (1985): Meaning and messages: mapping style in the Iberian Chalcolithic, Archaeological Review from Cambridge 4,3, 181196.

MALLON, A.; KOEPPEL, R.; NEUVILLE, R. (1934): Teleilat Ghassul I. Rome.

MALLOWAN, M.E.L. (1947): Excavations at Brak and Chagar Bazar. Iraq 9.

MARAN, J. (1998): Kulturwandel auf dem griechischen Festland und den Kykladen im späten 3. Jahrtausend v. Chr. Studien zu den kuturellen Verhältnissen in Südosteuropa und dem zentralen sowie östlichen Mittelmeerraum in der späten Kupfer- und frühen Bronzezeit. Universitätsforschungen zur prähistorischen Archäologie 53, Dr. Rudolf Habelt, Bonn.

MARGUERON, J. (1983): Mari. rapport préliminaire sur la campagne de 1980, Mari. Annales de Recherches Interdisciplinaires 2, 9-35. 
MARGUERON， J. (1992): The 1979-1982 Excavactions at Mari: New Perspectives and Results. In: Young, G.D. ed., Mari in retrospect. Fifty years of Mari and Mari Studies, 217-232. Winona Lake.

MARGUERON, J.-C. (2004): Mari, métropole de l'Euphrate au IIIe et au début du IIe millénaire avant J-C., Paris.

MARTIN SOCAS, D.; CAMALICH MASSIEU, M.D. (1982): La 'cerámica simbólica' y su problemática. (Aproximación a través de los materiales de la colección L. Siret). Cuadernos de Prehistoria de Granada 7, 267-306.

MELLINK, M.J.; FILIP, J. (1974): Frühe Stufen der Kunst, Propyläen Kunstgeschichte 13, Berlin 1974.

MOLINA-BRUGUERA, G.; PEDRAZ PENALVA, T. (2000): Nuevo aporte al eneolítico valenciano: La Cueva de Las Mulatillas (Villargordo del Cabriel, Valencia). Anales de Prehistoria y Arqueología 16, 7-15.

NOCETE, F.; VARGAS, J.M., SCHUHMACHER, TH.X., BANERJEE, A., DINDORF, W. (2013): The ivory workshop of Valencia de la Concepción (Seville, Spain) and the identification of ivory from Asian elephant on the Iberian Peninsula in the first half of the $3^{\text {rd }}$ millennium B.C, Journal of Archaeological Science 40, 1579-1592.

NORTH, R. (1961): Ghassul 1960. Excavation Report. Pontificio Istituto Biblico, Analecta Biblica 14, Rome.

PARROT, A. (1956): Mission Archéologique de Mari, vol. I. Le temple d'Ishtar, Paris.

PASCUAL BENITO, J.LL. (2009): Idolos oculados sobre huesos largos en las cuencas del Júcar y del Segura, in: In: Cacho, C.; Maicas, R.; Galán, E.; Martos, J.A. eds., Ojos que nunca se cierran, Museo Arqueológico Nacional. Madrid. (Edicción digital: http://man.mcu.es/publicaciones/OJOS/OJOS0902.html
PFÄLZNER, P. (2013): The Elephant Hunters of Bronze Age Syria, in: Cultures in Contact from Mesopotamia to the Mediterranean in the Second Millennium B.C., 112-131, New York.

PLA BALLESTER, E.; MARTÍ OLIVER, B.; BERNABEU AUBÁN, J. (1983): Ereta del Pedregal (Navarrés, Valencia). Campañas de excavación 1976-1979. Noticiario Arqueológico Hispano 15, 39-58.

PLA BALLESTER, E.; MARTÍ OLIVER, B.; BERNABEU AUBÁN, J. (1983b): La Ereta del Pedregal (Navarrés, Valencia) y los inicios de la Edad del Bronce. In: Congreso Nacional de Arqueología 16, Murcia- Cartagena 1982: 239247. Zaragoza 1983.

RENFREW, C. (1969): The Development and Chronology of the Early Cycladic Figurines. American Journal of Archaeology 73, 1-32.

RIEMSCHNEIDER, M. (1953): Augengott und Heilige Hochzeit. Fragen zur vorgeschichtlichen Religion 1, Leipzig.

RODRIGUES, M. da C. M. (1986): Estudo ideológico-simbólico das placas de xisto gravadas. Vol. II: Alto Alentejo, Câmara Municipal, Castelo de Vide.

SCHMIDT, H. (1902): Heinrich Schliemann's Sammlung Trojanischer Altertümer. G. Reimer, Berlin.

SEEHER, J. (2000): Die bronzezeitliche Nekropole von Demircihüyük-Sariket, Istanbuler Forschungen 44, Ernst Wasmuth, Tübingen.

SOLER DÍAZ, J.A. (2002): Cuevas de inhumación múltiple en la Comunidad Valenciana, Vol. 2, Madrid/Alicante.

YAKAR, Y. (1985): The Later Prehistory of Anatolia. The Late Chalcolithic and Early Bronze Age BAR Int. Series 268, Oxford. 